\title{
A Critical Analysis of Athol Fugard's Social Vision in Four Selected Plays
}

\author{
Mwihia Margaret Njoki
}

Mount Kenya University

Email: njokimwihia@yahoo.com

\section{Dr. Collins Ogogo}

Mount Kenya University

Email:ogogocollins@hotmail.com

\section{Doi:10.5901/jesr.2014.v4n1p63}

\begin{abstract}
Literature is a product of the writer's artistic imagination. The writer accurately observes the happenings in his/her society, both contemporary, and historical and communicates to the readers through use of vivid imagination and creative use of language. His/her her aim is to communicate and have an aesthetic impact upon the reader. Writers, thus fuse history in their creative works. Indeed, literature gets shape and direction from society. The shape is derived from society's experiences in terms of the raw experiences of the society. These raw experiences also dictate the kind of literature; in terms of the techniques and styles that the writer uses to communicate his/her vision. Though a writer may present the realities of his/her society, such realities cannot be fully objective. Literature is fiction; it presents a writer's perspective and perception of a society's realities. Thus writers aim at persuading the readers to take a certain attitude towards the realities. What they present is a slice of life; a selected paradigm of the realities. South African literature was mainly shaped by the experiences of black South African; the experiences arising out of the system of Apartheid. However different writers present different perception on the psychological and physical effects of this racist system that dehumanized the black people. Through use of different literary techniques and styles the writers are able to interrogate the ideals of Apartheid system and make artistic judgment on the values that the system entranced. This study examines the artistic vision in four of Athol Fugard's plays as communicated through the techniques and styles that he employs for aesthetic communication. The study recognizes the fact that though literature is indeed given impetus and direction by society, the artist cannot just document that realities like a historian or sociologist. The artist aims at creating an aesthetic impact upon the readers. This impact can only be achieved through the writer' artistic judgment on what is communicated. Elements such as characterization, choice of diction and the general tone of the work thus become crucial in communicating the writer's vision.
\end{abstract}

Keywords: Literature, Language, Arts, Writers, play

\section{Introduction}

Literature as creative works of imagination is characterized by accurate observation of the environment, vivid imagination and ingenious use of language. From an artistic angle, writers use their imagination to explore peoples' values from different dimensions. However as Ngugi (in Gachukia and Akivaga eds.1978) has correctly observed, literature does not grow out of a vacuum; it is given impetus and direction by society. Ngugi's observation implies that a writer's work is shaped by the different experiences that his/her society has undergone. These experiences could be socio-political, economic, religious, and historical among others.

Ngugi goes on to argue that literature results from conscious acts of human beings in society. He states:

At the level of the individual artist, the very act of writing implies. A social relationship: one is writing about somebody for somebody. At the collective level, literature, as a product of men's intellectual and imaginative activity, embodies in images and words, the tensions, conflicts, contradictions at the heart of a community's being and process of becoming(in Gachukia and Akivaga, eds. 1978, p. 3)

Literature therefore is a reflection of at the aesthetic and imaginative plane, of a community's struggle with its social total environment. Indeed a writer does not come from a vacuum; he/she comes from a particular class, nation or race; he /she is a product of actual socio-political, historical, economic and other experiences close. 
According to Nyamdi( 2006) Africa's literature close and even organic link with the African society that it reflects settles a pathfinder role on this literature. He adds that Africa goes where its literature takes it. This observation presupposes that the African writer has a great role in the education and re-education of his/her people. Indeed retrospection in African literature is not just reproduction of African history; it is writers' artistic techniques of moving away from the real to the ideal. Out of the raw materials of history the African writer constructs for us fictions; in so doing they create patterns of meaning out the jumble of fragmentations and chaos that the African reality presents.

Through his/her creative imagination a writer aims at persuading his/her reader to view not only a kind of reality, but more important from a certain angle and perspective, a certain vision, though perhaps unconsciously. The writer's creative work both reflects reality and also aims at making the readers take a certain attitude to the reality presented.

Many illustrations from modern African literature indeed reveal the artistic chronicling down of the real sociopolitical, economic and many illustrations from historical realities on the continent.

La Guma (cited in Wanajala 1973) observes that African literature concerns itself with the realities of Africa. This standpoint seems more realistic. Here there is the possibility of defining the reality, the social and political background that engenders the production of a work of art. For the African writer this should not evoke shame for it is true that all literatures of the world seem to have been created by particular social, political and economic factors prevailing at the time.

Expressing African reality, in an appropriate style and form in turn mirrors the writers' vision. African reality is that we are products of many cultures and historical circumstances. Most African writers from Achebe, Ousmane Sembene, Alex La Guma, Mazizi Kunene, Ngugi wa Thiong'o among others have successfully communicated African reality through their creative works, and by means of artistic judgment suggest the ideal; presenting their artistic judgment of the reality reflected in their creative works.

In South Africa writers, particularly black writers seem to have been influenced more by the ideals of the Apartheid system. This literature reflects the historical context of the country, the social and political scene in Apartheid South Africa. The Dutch, 'Boers' got to South Africa before the British in the $19^{\text {th }}$ century. They confiscated the people's land, later the British came and initiated the Anglo-Boer war between 1899-1902. The Blacks supported the British who won and then started the minority rule in South Africa.

The question of colour became a great problem in South Africa and was used as an excuse to exploit the blacks. In 1910 the British passed an Act of Union that denied the Africans the right to vote. It upheld colour Bar and blacks couldn't struggle for economic and political emancipation.

Several Acts were later passed that legalized segregation in terms of jobs, housing, education, social position movement etc. Restriction in housing can be seen in the fact that blacks were confined to the reserves called Bantustans e.g. District Six in Alex La Guma's Novella 'A walk in the Night'. Movement of blacks was also restricted as we see in Alex La Guma 'In the Fog of the Seasons End. The Pass system governed the lives of the blacks.

In 1948 apartheid was adopted as an official policy and was perpetuated by the capitalist system. The system allowed for the discrimination of blacks in employment, housing, education and many essential needs. The main focus of these writers was a reaction towards their situation: apartheid. They challenged the regime and expressed bitterness in their writings. The writing from South Africa initially took the form of autobiography focusing on the slum life, Soweto, Sharpeville Massacre of 1970's.

Generally the apartheid system stripped Blacks of human dignity and this is the reality that the writers put in their fiction. There was also protest poetry reflecting the people's condition like Denis Brutus or Steve Biko's poetry. In South Africa, there were also white South African writers e.g. Allan Paton, of Cry the Beloved Country who opposed the white regime in his book.

Because of the brutality inflicted on Blacks in S. Africa and because of the evils of the apartheid system, African National Congress was formed in 1912 as a peaceful struggle against segregation, but was later out-lawed and became an armed struggle and went underground. Like many other nationalistic movements in Africa there was a lot of optimism, looking forward for a better South Africa.

Athol Fugard's works are not different from other creative works from South Africa, perhaps in terms of exploring the psychological and physical effects of the Apatheid system on blacks. Indeed many critics of South African literature tend emphasize the theme of apartheid. This study, however, moves beyond theme to explore Athol Fugard's artistic vision as presented in four of his published plays: Hallo and Goodbye (1965), The Island (1972), Master Harold and the Boys (1982) and Blood Knot (1987).

The study is premised on the recognition of the fact that a writer does not only reflect the realities within a particular context but makes an artistic judgment of the same from an aesthetic plane; presents his/her vision on the raw 
materials of reality presented.

\section{Research Design and Methodology}

A research design is the arrangement of conditions for collecting and analysis of data in a manner that aims to combine relevance to the research purpose with economy of procedure (Kothari 2003, P. 39). It is the conceptual structure within which research is conducted. It calls for definition of research problem. It constitutes the blue print for the collection, measurement and analysis of data (Kothari 2003 39). The study being a library based textual analysis used the descriptive design. The design allowed the researcher to critically read the texts and give her opinion in terms of how Athol Fugard's drama communicates his vision.

A critical analysis of the selected plays was undertaken with the aim of interrogating and analyzing how the plays communicate the writer's vision. Being a textual analysis design, the texts were read critically in line with the objectives of the study.

Also vital to the appraisal of the texts was library research. Library research provided information on needed sources of books and even criticisms from other researchers. This aided the researcher in the understanding of the research topic and analysis of the problem and the research questions.

Primary data was collected from the primary sources. Secondary data was collected from various libraries. Secondary sources were handy in supporting the researcher's prepositions and also relating the analysis and conclusions of the study to what other researchers have done. The information also allowed the researcher to determine the gaps in knowledge so as to avoid duplication. Additional information was obtained from the internet and various critical texts.

The relevant information collected from the sources already mentioned including the libraries was read and analyzed in respect to how relevant they were pertaining to the topic of study. The primary data from the analysis of the selected plays was analyzed in relation to the objectives of the study. The analysis is presented in line with the objectives of the study.

\section{Theoretical Framework}

The proposed study is grounded in the New Historicism theory. This is a school of literary theory that developed in the 1980s, primarily through the work of the critic Stephen Greenblatt (Abrams, 1999).

New Historicists aim simultaneously to understand the work through its historical context and to understand cultural and intellectual history through literature, which documents the new discipline of the history of ideas. According to (Lynn 1998) Michel Foucault based his approach both on his theory of the limits of collective cultural knowledge and on his technique of examining a broad array of documents in order to understand the happenings of a particular time. New Historicism is a more neutral approach to historical events, and is sensitive towards different cultures. New Historicism seeks to find meaning in a text by considering the work within the framework of the prevailing ideas and assumptions of its historical era. New Historicists concern themselves with the political function of literature and with the concept of power, the intricate means by which cultures produce and reproduce themselves. These critics focus on revealing the historically specific model of truth and authority (not a "truth" but a "cultural construct") reflected in a given work (Abrams 1999).

As a literary theory, therefore, New Historicism serves well in showing how works of art reveal historical truth or the real and how writers subjectively communicate their artistic judgment, the ideal. In other words, history here is not a mere chronicle of facts and events, but rather a complex description of human reality and evolution of preconceived notions. Literary works may or may not tell us about various factual aspects of the world from which they emerge, but they will tell us about prevailing ways of thinking at the time: ideas of social organization, prejudices, taboos, etc. ( Lynn 1998). They raise questions of interest to anthropologists and sociologists. New Historicism is more "socio-historical" (Murfin et. al. 1997). It is concerned with ideological products or cultural constructs which are formations of an era. New Historicism insists that ideology manifests itself in literary productions and discourse.

New Historicism guides the study in appreciating how literary productions are grounded in particular historical realities and manifest certain ideologies in terms of the writer's artistic vision. Indeed, as noted elsewhere, creative works of are products of time and space and may reflect the same but from an aesthetic angle.

This study also benefits from stylistics as a literary theory and methodology. The study concurs with Lubbock's assertion that in a good work of art content and form are inseparable (1957, p. 23). Such elements as literary techniques 
and styles are significant in the consideration appreciation of any work of art: for these are what create the communication effect that ultimately reflect the writer's vision. The present study therefore employs the stylistic approach in the study of Athol Fugard's vision in the selected four plays. This approach considers literary language as an important tool for communication in any work of art. As Stephen says, one aim of stylistics is to define the work of literature in terms of its patterns of speech, diction, sentence structure and imagery (1991, p. 349). Stylistics thus concentrates on the style of a work and how an author chooses to express himself. Stylistics also considers a work of art as a reflection of the author's appreciation of his own cultural environment. Stephen (1991) argues that stylistic interpretation of a work of art can be related to author or sociological, historical and biographical features. The stylistic approach is thus adopted for its relevance as the main descriptive theory of the literary text.

The artist is a member of society and uses literature as an avenue to express the society's experience and at the same time communicate hi/her vision. Literature is produced within a social environment and a historical period. Since literature is a creation of the individual member of society, it does not only reflect the experiences of the society but also seeks to influence the same society. This study recognizes the relationship between the artist and society on the one hand, and the relationship between literature and society, on the other. The two theoretical frameworks are therefore appropriate in the study of Athol Fugard's vision as reflected in the four sampled plays. The dialectical relationship forms the framework upon which this study is grounded in.

\section{Review of Literature}

\subsection{General review}

Works of critics who have studied Fugard's plays and those reviewers who have done some reviews of his plays have been examined as a way of finding out gaps that the current research aims at filling and also as a means of augmenting our argument. Osundare (2000, p. 20) in an interview notes the inter-relationship between literature and the society. He states the following:

We have to stress this, because we live in a world in which in some parts at the end of the twentieth century, people just think that Literature doesn't matter. They have forgotten that Europe and America wouldn't have developed to the state that they are now without the works of Homer, without the works of Virgil, without the works of Chaucer and Shakespeare. All these works prepare the minds of the people, sharpened and refined their sensibility. I don't know whether there would be any science if there hadn't been literature.

The above observation indicates that there is a relationship between literature and the society. Literature is a product of society. It points out how sensitive literature is to the society in recording events and situations through language, and also as an agent of promoting development by propagating social values.

This is what Wastberg, (1988, p. 20) means when he writes, "a writer is a connoisseur of power. In his very profession lies power to influence." A writer cannot stand aloof to his/her social realities. The recognition of this truism makes it necessary for scholars of literature to study not only the relationship between literature and society but more important the artistic judgment in works of art.

Kirsten, (1988 p. 9) reports that Wole Soyinka in his submission to the Second African Writers' Conference asked the writer to be true to his heritage, which as he states is to be not just 'the recorder of the moves and experience of his society,' but also 'the voice of vision in his own time'. In regards to the study's topic in the realm of social vision, Soyinka further observes that the author must not content himself with chronicling the customs of society. "He must play the part of bard and oracle, he must see more clearly and exactly than other people, he must be a visionary, a warning voice and a builder of the future." (Quoted in Kirsten, 1988, p. 9). This study examines Athol Fugard's drama in terms of how it communicates the playwright's vision.

Wanjala, (1970) says of literature "Literature influences life of people and reflects tensions within groups as well as within individuals. It also uses imagination." The term literature is best described as imaginative literature. Language therefore becomes very central in literature. Literature is a social phenomenon i.e. it has a social meaning whether the author be aware of it or not. The creation of literature becomes a social art because creativity is a highly complex organization of character with multiple meaning and relationships. Wanjala's observation gives us more insight into the nature of literature and the relationship between literature, society and the writer.

In an essay on John Keats, (1795-1821) Paul de Man indirectly shows the link between literature and the artist. He suggests that Keats should be regarded as a prospective writer unlike William Wordsworth, (1770-1850) whose work is 
retrospective. According to de Man Keats' work 'consist of hopeful preparations, anticipations of future power rather than meditative reflections on past moments of insight and harmony'( cited in Royle, 2003, p.103). De Man suggests that Keats' work has a future vision.

De Man's view of Keats seems to us a particularly attractive finding, and one which stands African literature in good instead. Arguing for greater concern with the future in African writing will be the main thrust of our effort here. The tradition among the great majority of African writers to undertake a curative pilgrimage into their society's past has come to be viewed as self-evident. That return seems to be validated by no other reason than that Africa needs to redeem its shattered past, a consensus having been reached that Prospective Commitment in African Literature.

Soyinka's cautionary note alerts the modern consciousness to a totally different reality. That the African past deserves attention is in no doubt. But what should be the focus of that attention has continued to generate quite some controversy. The dominant view, ever since Achebe's ground-breaking novel Things Fall Apart holds western civilization responsible for the African predicament. This view sanctifies the African past, makes of it a venerable age of great achievements and entente, then indicts European explorers for abruptly and in certain cases brutally bringing that great age to an end. The need is felt, therefore, to chronicle the disintegrative process with a view to restoring the grandeur of old.

This exercise in clinical historiography Soyinka condemns. And his position situates itself on a road travelled earlier by the likes of T.S. Eliot. Among the many insights with which the latter mind has studded the landscape of modern thought belongs his view of contemporary history as an immense panorama of futility and anarchy (Kermode, 1975: 177). Eliot was a scholar of anarchy, reader of a world ordered by chaos and meaninglessness, of which The Waste Land constitutes the finest poetic epitome.

Eliot's essential nihilism was suggested to him by humanity's track record, bleak and chaotic in the main. He looked around him into the prime movers of human action and discovered that only very rarely did man dedicate himself to the welfare of his species. This discovery, however, did not dull his optimism. He nurtured the hope that the chaos could be defeated, basically through a continuous exploitation of the parallel between contemporaneity and antiquity. He saw in a structural awareness of this kind the best means of giving shape and significance to history, the responsibility for such a task lying ideally with the writer, whose powers of constructive retrospection would invest history with a new role, that of wellspring of human valour.

Writing much later in the day, but in the footsteps of his English predecessor, Nkosi, (1981: 32) also views history as "a conspiracy of malevolent forces." And just like Eliot, he ascribes to the writer a redemptive mission: "Out of the raw materials of history the novelists construct for us 'fictions'; in so doing they create patterns of meaning out of a jumble of meaningless chaos" (Nkosi, 1981: 31-32). Nkosi's observation is significant to this study because our focus in on how Fugard fuses history into his drama and ends up communicating his vision on Apartheid South Africa.

What Eliot calls shape and significance, and Nkosi patterns of meaning are redeeming strengths that underline history's ability to wrest itself from chaotic negativity and transform into source material for human worth. History incessantly confronts the writer with a jumble of meaningless chaos. His duty is now to extract from this jumble, such elements as can restore meaning to existence, now and tomorrow, and to craft such elements into works for the vivification of his society. Thus the African writer cannot just document African history but be selective and artistically reveal his/her vision. Ngugi Wa Thiongo, (1993, p.50) succinctly:

I believe that African intellectuals must align with the struggle of the African masses for meaningful life. For we must strive for a form of spirit and energy of our people and a new country, and sing a new song. Perhaps, in a small way, the African writer can help in articulating the feeling beyond this struggle

It has been established that Fugard has articulated the feelings of the readers through the characters as Ngugi, (1981, p.80) also argues in Writers in Politics that a writer must 'Show commitment' to the 'actual struggle of the African people'. In his collection of essays in Homecoming, (1972, p.47) Ngugi perceives an artist's literary works as reflecting his experiences as well as those of the society from which he lives. Fugard has communicated his feelings as well as experiences through those characters that have been established to carry his social vision in the four plays.

Fugard's works have received some criticism from researchers and critics of South African Literature. Wertheim, (2000,p.1) states that his own study on Fugard's dramatic art is meant to be a discussion on all his plays on what is called 'the playwright as a thinker' and he examines Fugard's ideas for a modern theatre audience. This study is justified in that it focuses on Fugard's social vision for all the races regardless of age, gender and the way he communicates it through four selected plays. It critically examines how the playwright prepared his audience for transition in his social vision. Although these plays were set decades before the demise of apartheid at a time when the racial segregation law 
was in place, it has been found to be essential to examine them to establish how Fugard addresses the issue of apartheid and his vision of redemption amidst opposition. It was not easy for Fugard to communicate his vision as the apartheid law did not allow the races to interact. "True enough Alan Paton cannot travel abroad nor can the playwright Athol Fugard"(Mphalele, 1972, p. 214).According to the apartheid laws, the races were not supposed to relate socially, so as aid earlier, when Fugard opposed the regime through his art, he was denied travelling outside South Africa. Anyone who spoke for the rights of the black race received a negative response from the regime. Mphalele, $(1972$, p. 214) also states that Alan Paton like Athol Fugard, was a white South African novelist who was also denied travelling due to producing works that castigated the apartheid system.. This study establishes how Fugard's social vision emerges in the plays despite the odds.

Fugard was opposed by his own race as well as by the blacks he was fighting for. "Fugard's dilemma had often been and would continue to be, that of being taken to task for writing about the degradation of the black and the coloured people while he himself was afforded the privileges enjoyed by South African whites". (Wertheim, 2002, p.2) This explains the opposition he got from his own race. At the same time, his skin colour deprived him of complete acceptance by the blacks he was fighting for because they saw him as a white man whose skin was their deprivation. The blacks most likely saw Fugard as necessarily seeing the life of the blacks and the coloureds at a distance. "This always kept him from truly understanding what it was to be a 'non-white' in South Africa and also what it was like to live in blows that only blacks and coloureds knew of with terrible immediacy"(Wertheim, (2002, p.2).

Despite these distracters, Athol Fugard continues in his task of writing more plays decade after decade opposing apartheid and working with his black friends as stated earlier. The study therefore is justified in examining what social vision he has that gives him the reason to write against a regime that is expected to naturally favour him as a white.

In his introduction, Fugard, (1987) says that when his play Blood Knot was staged on television by the British Broadcasting Co-operation (BBC), his passport was confiscated so that he could no longer travel abroad. This shows that he was trapped between the two conflicting races in his country. By virtue of his colour he could enjoy freedom of movement and expression but on the other hand he disliked the apartheid system that separated South African blacks from enjoying the same freedom the whites enjoyed. It was only because of the privilege of his white skin that his works as well as those of other whites were not banned although the message in them was against racial segregation and the apartheid regime. This was different for the black writers addressing the same issues as Mphahlele, (1972,p. 206) explains that he himself with other black and coloured writers including Alex La Guma another non-white South African novelist had to leave South Africa as they were declared prohibited immigrants in South Africa.

Gray, (1982, p.1) argues: "Critics were slow to contextualize his work due to the fact that he did not belong to the rich South African literary theatrical tradition". Fugard had the chance of writing due to his colour but his works got little attention from critics and scholars. This fact therefore justifies the researcher to examine these plays by this playwright whose works received minimal attention from his people because they found them as opposing their interests and hence of little or no importance in their regime.

These situations are as Tyson, (2006, p. 54) suggests: "From a Marxist perspective, differences in socioeconomic class divide people in ways that may be much more significant than differences in religion, race, ethnicity, or gender. This applies not only to South Africa but also to other nations of the world considering that literature is universal. Vices may not necessarily emanate from racism like in the case of South Africa but could also apply to any other causes like social class, economic status or ethnicity which could be found anywhere else in the world. The study has done a critical examination of Athol Fugard's social vision for the South Africans regardless of their skin colour.

On the other hand the black scholars were preoccupied in looking at literary works by non-whites because they had no trust for the whites due to the way they suffered under them. In this way, the blacks who ought to have supported him left his works out due to mistrust. This mistrust among the blacks and whites is a major vice in South Africa brought about by racial segregation. Mphahlele, (1972, p.214) asserts:

As long as a white man speaks up for this underdeveloped person; it is not bad...Paton's books are not banned, nor Fugard's plays.

It is therefore evident that Fugard's works also missed considerable attention from African critics due to his colour as opposed to the black and coloured writers of his time (Gachukia, (1978, p.214). Alex La Guma a coloured South African writer is an example who got attention from Duerden, (1972); Rive, (1963); Parker, (1978); Abrahams, (1972) to mention a few. A black man who wrote the same things the liberal-minded among the whites wrote and represented the same liberal and egalitarian ideas would most likely lead to his exile.

Abrahams, (1958, p.164) concurs with Gachukia by asserting that: "The other side of the South African fiction coin 
is one of unmitigated suffering white subjugation, of protest and conflict". This tells how the racial laws discriminated the non whites making them lose confidence in them and hence the reason for Fugard's works being left out by non white scholars. Wertheim, $(2000$, p.3) states that, Fugard went on producing his plays dodging here and there but with a back wash of guilt. This is because he was going against the political wind of his race. The study is therefore justified in giving additional insight by researching into a white man's social vision in his plays that he wrote in the middle of opposition due to colour bias. The study is thus justified and examines the four selected plays for Fugard's social vision. It is hoped that the study will be an additional research to others on South African artistic works and will also serve as a challenge for other scholars to try and work on the other plays by Athol Fugard and establish the message it has in preparation for transition for South Africans.

The grim picture of the black race suffering in the hands of the white man has dominated the criticism of South Africa's literary landscape since the dawn of apartheid in South Africa. Although apartheid came to an end with the historical release of Nelson Mandela from prison in1992, the study has examined Athol Fugard's social vision for all the races of South Africa considering that the different races were used to living separate lives before the dawn of emancipation which came with Mandela's release. Gachukia, (1978, p. 196) posits: "The white man was consolidating his position and issuing manifestos about separate development" and this formed the basis of apartheid. The main focus of this study has been to critically examine and analyze Fugard's characters and the roles he gives them as he endeavours to establish his social vision.

Gordimer, (1958, p. 36) asserts: "I want to take care of my own relationships with men and women who come into my life, and let the obstructions of race politics go hang" The study has critically examined Athol Fugard's four texts which were all set during the apartheid era to elucidate his social vision and its inclusiveness regardless of race, gender, creed and age in the citizens of South Africans through his fictional characters. Regarding the suggestion by Inkels, (1964), that in the field of sociology, the family, politics, religion and social control are of great importance, this study has looked at the interaction of Fugard's characters as of great essence in analyzing his social vision. Athol Fugard's characters are examined critically in regards to the playwright's vision which can also be considered as his dreams for his homeland. In communicating his vision the playwright uses different dramatic techniques. The playwright's style is established through the language used by the characters. This study has looked into the social situation of the characters, common apartheid practices, polyphonic depiction of characters and Fugard's relevance as he communicates his social vision through the different roles he gives them against the backdrop of apartheid.

\section{Critical Works on Fugard's Drama}

As a prolific artist, Athol Fugard has received his share of critical attention. However most of it is in form of interviews, essays, articles in journals and on the internet. Albert Wertheim has however written a whole text The Dramatic Art of Athol Fugard, (2000) and examines many of Fugard's plays as he states: "The study of Fugard's dramatic works is meant to be a discussion of all his plays to date focusing on the playwright as a thinker" (Wertheim 2000, p. ix). He examines Fugard's ideas as well as his ability to use the dramatic form in order to give shape to his ideas, present them alive and make them alive on stage for modern theatre and audiences. In his research on Athol Fugard's dramatic art, he sees the art generally as a chronicle of South Africa in decades of apartheid and after. He begins from the earliest text Klaas and the Devi,I (1956) all through to the recent one The Train Driver, (2010).

Included in the collections are the texts of this study and he gives some analysis but does not go into the details about either Fugard's vision or preparation for the new era that came with the historical release of Nelson Mandela. He tells about how Athol Fugard and his black friend Mokae starred as the actors Morris and Zachariah in Fugard's The Blood Knot,(1962) which was later revised as Blood Knot (1987). He just retells the story as he also does for The Island, (1972) but elaborates that this play was inspired by a true story based on the South African notorious Robben Island where Nelson Mandela was held prisoner for twenty seven years. He explains that Fugard's first plays No Good Friday, (1958) and Nongogo,_(1959) were both set among Sophia Town blacks and they weave together the realism or naturalistic setting of a township. He observes that the characters face the same issue which is the poverty imposed on the blacks of South Africa and that to be black in South Africa is to be poor. This observation is important in this study in that it identifies there is a racial gap in the characters that needs to be examined in search of Fugard's social vision. He explains the importance of Fugard's work as not only for launching his career as a highly regarded playwright but as a signifier in the development of his thinking and theatrical style. However there is no mention of the social vision he has and hence the reasons for this research study to examine it.

Wertheim also posits that Blood Knot, (1978) as well as Hello and Goodbye, (1965) which are two texts of this 
study was both Port Elizabeth plays that took place in single rooms but he does not discuss anything about Fugard's vision for the characters. He however observes that they both attacked apartheid which is in the interest of this study. In another play, known as Statement_(1974) he states that the audience is forced to confront the effects of South African law prohibited sexual relationship and marriage between members of different races. In yet another text, Fugard's Master Harold and the Boys ,(1982) and another one though not one in the study, A lesson From Aloes, (1972), he states that Fugard needed to bring together an understanding of interpersonal psychodynamics with the question of race, an amalgam that characterizes the two plays. This is in line with the study in dealing with the characters socially and psychologically. He describes Road to Mecca, (1984) as a difficult play and one that resonates at many levels using the drama to contemplate the nature of art and the artist. He suggests that the answer to South Africa's vexing social problems which are very much the product of conservative Afrikaner intransigence will be found by marrying that very stubbornness and tenancy to an inspired vision of freedom. He however does not show how Fugard's vision prepares his characters for that marriage.

Even when he expresses how $A$ place With the Pigs, (1987) deals with either remembered incidents or with the painfulness of the present, it is without any mention of Fugard's vision. With another one of Fugard's plays written later, My Children My Africa,(1989) Wertheim explains that there is recognition that apartheid days are numbered and a new generation of young people, black and white, stand on the threshold of the future without also a mention of the vision which is the interest of this study. He argues that the play Dimetos,(1978) goes to the heart of an essential matter that arises time and again in Fugard's works including the plays of this study. This is the connection between the making of theatre and the making of life, and between the art of theatrical acting and life itself. This shows Wertheim's concern for the dramatic art. However for this study, the main concern is the social vision and preparedness for the characters to adopt an apartheid-free life.

Gray, (1982, P.1) states that: "Although Fugard is a well known contemporary dramatist there were relatively few studies covering the entire spectrum of his work." As for another text of the study Hello and Goodbye, (1965), he retells the story. He also does the same for the other plays of this study Master Harold and the Boys ,(1982) which was first produced at Yale repertory theatre in (1982) but was banned in South Africa. The reason Gray gives is that critics focus only on individual plays and Fugard's biography. He states that he himself has done two of his most informative books on Fugard and they are no more than collections of reviews, interviews and essays. In some of the collections by Stephen Gray in the year (2008), he describes Athol Fugard as a South African writer who attacked the apartheid system in his works. Gray narrates the life story of Fugard from his birth and goes on to tell about his works but has no mention of the playwright's social vision thus justifying the need for this research study.

MacDonald ,(2002) and McLuckie, (2003) also have looked at some of Fugard's plays and they describe him as a dramatist of enormous power who uses a small cast. Their focus is on the drama but again they do not talk of the social vision. February, (1981,p.69) states that Athol Fugard in The Blood Knot, (1963) which was the first version of his other title where the article 'The' is removed to read as Blood Knot,(1978) which is one of the texts of this study, portrays a realism in which the non-white is at least a victim of the system's ascribed roles. For this study, the interest has been on both the non whites and the whites and what vision the playwright has for them.

As regards Fugard his influence is as Per Wastberg in the Introductory Essay quoted in Criticism and Ideology: Second African Writers' Conference Stockholm, 1986 where he observes that South African scholars have tried to address the problem of censorship, and although they agreed that censorship had recently become less harsh they also agreed that things in general had become worse. Some of the numerous numbers of articles about Athol Fugard's plays that have been recorded in journals are Stephen Holden's fifty six articles in the year 2011. They have information on the politics of Fugard's works. A Journal article by Don MacLennan 'A tribute for Athol Fugard at sixty' has information about Fugard's works as a playwright, novelist, actor director and recipient of many awards which is essential for this study.

Daniel Lehman in journal articles on Research on African Literature in 2011 observes that in Fugard's novel Tsotsi Transformed: Retooling Athol Fugard for the Thambo Mbeki states that it symbolizes what South Africans can achieve when they work together towards a common objective. In this study, the vision and preparedness for the new era in the characters is examined.Stephen Holden's fifty six articles on politics in the journal article 'Project Muse' edited by John Hopkins University press in (2011) have explored extensively into Fugard's novel Tsotsi Transformed which also alludes to the interest of this study but still does not lead to the social vision.

A review by Elaine Vaan Hogue in the year 2011 in the England journal of the aesthetics, on Fugard's play The Road to Mecca, (1984) establishes that the audience is exhorted again and again to live bravely, fight injustice and love one another forever. This has been important in this study in trying to establish Fugard's vision. Mike Klindo and Helen Halyand in the year 2006 produced a literary writing that is entitled as Tsotsi: Can a Baby Redeem a Hardened Thug? 
This was initially a novel that was converted into a film. It was directed by Gavin Hood and talks of Fugard as an opponent of apartheid. However, this study went beyond the opposition and dealt with Fugard and his social vision.

As Wade, (1993 p.1) notes, Nadine Gordimer another white South African writer recognizes that: "The myths white South Africans construct of black South Africans are sexually a threatening function". This study is however interested in the social vision Fugard has for the different races in South Africa. The Island,(1973) is yet another play of this study and he asserts that it is indeed an actor's play for acting is its central metaphor and idea and also acting as a means for the acting out of one's life, acting as a form of survival and acting as a basis for political action. This study is involved in examining characters in the plays to determine what social vision Fugard has for his nation. In the play Sizwe Bansi is Dead, (1972) he explains the menace of the blacks and how difficult it was to stay out of trouble. The study has examined how Fugard deals with this menace through his characters and established the use of figures of speech.

In an article shown in the internet by Brendan Gill in (2011), he describes aloes as a kind of plant growing in South Africa. It is prickly and not pleasing to look at but survives in a hostile climate. He states that the lesson from the aloes is that even against high odds life can assert itself and prove worth living. Our literature review reveals that Fugard has received some criticism from different critics. However many of the critics have taken a more thematic and historical approach. This study deviates from this common tradition and focuses more on Fugard's vision, artistic vision as communicated in the selected plays.

\section{Analysis of Fugard's Social Vision as Presented in the Plays}

Fugard presents his Social Vision in four books, namely, Blood Knot, The Island, Master Harold and the Boys, Hallo and Goodbye. This section will make a brief a discussion of each of these books while showing how Fugard presents his Social Vision.

\subsection{Fugard's Social Vision as Presented in Blood Knot}

In Fugard's Blood Knot the playwright begins by expressing the situation of the blacks in South Africa.

In 1958 the second year of our marriage, we moved to Johannesburg, where I found a job as a clerk in the commissioner's court... Every black man and woman had to carry a pass - book, the endorsement which decides where he may live, work, travel etc. Any violation of this endorsement is a statutory offence and is dealt with in a Native Commissioner's court. The usual sentence is about two week's imprisonment $(1987, p . v)$.

Here we learn that there are two entities. The whites have the upper hand as they are the ones punishing those blacks who go against the pass law while the blacks are the ones who are being oppressed by the pass law. The pass law is meant to control and restrict the blacks in their own land as Durosimi and Jones, (1996) states. This is a matter that has also been established in the in the four plays. In Blood Knot Zachariah the black person works as a sentry at a factory gate where he is confined to a standing position daily. Zachariah's feet get sore and swollen as a result of standing in the same position for too long. However he can't vacate the job because he is restricted to move elsewhere by the pass law. Zachariah's boss is not willing to change his position for another because he looks down upon the blacks.

Fugard doesn't stay long in his clerical job as he later gets himself into writing plays drawing his material from what he sees in the slums when he visits his friends. He addresses the ills done to the blacks by the whites in his four selected plays. It has been established that he doesn't like the way the blacks are treated through the roles he gives to his characters. He vents his feelings through his characters. He gives his black characters the disadvantaged roles making the audience sympathize with them. The white characters on the other hand are given negative roles that make the audience feel alienated to them. The audience feels pity for Zachariah as he is made to stand at the gate for long hours so that his feet are swollen. The employer ignores Zachariah's plea for a change of job and also torments him. This is expected to brew hatred from the workers towards the employer as a result of the animosity bestowed on Zachariah. Each race would want to identify with their person and the result is alienation between the blacks and whites. The blacks are expected to identify with Zachariah and harbour some grudges against the whites who are the employers. Fugard's social vision is for the people of South Africa to live like brothers.

Wertheim, $(2000, p .2)$ earlier suggests that the playwright sees the lives of the blacks and coloureds at a distance as he is advantaged by his colour which amounts to superiority in South Africa. This however does not blind him from seeing the evils committed by his race against the blacks. He points out the fact that because his colour allows him the 
freedom to write, Athol Fugard continues writing amounting to the advantage of his social vision. His race however doesn't like his works for the reason that they unearth the situation of the colour discrimination in South Africa but he is not discouraged therefore he continues writing. Morris has pity for his brother and keeps on urging him to ask the boss to change his job for another convenient one but it is all in vain. The boss is not ready to listen to Zachariah's grievances because he is a white and Zachariah is black. Morris like Fugard has pity for his black brother but there is nothing he can do but hope that one day things will change and the whites will be human to the blacks.

Fugard is trapped between his love for humanity and his race. Although he as a white enjoys the freedom of movement and expression, he doesn't like the way his people treat the blacks. The playwright however is a white and there are some privileges that he enjoys because of his colour unlike the black writers. Mphahlele, $(1972$, p.214) argues that black writers like Alex La Guma and himself among others had to flee South Africa and go to exile because of addressing the same issues that white writers like Alan Paton, Nadine Gordimer and Athol Fugard among others continued to write about in freedom. In emphasizing this fact, Mphahlele adds that Alan Paton the writer of Cry the Beloved Country criticizes apartheid through his black and white characters and still enjoys a home in South Africa. He also cites another white writer Nadine Gordimer in her numerous number of novels as also attacking apartheid but is still comfortably living in South Africa while the black writers have to flee for dear life. However, like Fugard she is also opposed to apartheid. In one of her texts $A$ World of Strangers, $(1958, p .36)$ Gordimer states that she wants a South Africa where she can take care of her own relationships and associate with whomever she chooses. She despises the politics of colour. It is then evident that the blacks live an extremely different life from the whites although they are in the same country. Peter Abrahams in Tell Freedom, (1954, p. 250) posits:

\begin{abstract}
People move towards one another only so far and then, some kind of fear seems to descend suddenly upon them and then they hesitate... many white social workers who seemed untouched by the racial disease of the land... But there had been restraint: an unspoken, unexpressed concern lest they go too far in their intimacy or lest I forget that outside these offices of the (Institute of Race Relations) the racial laws were still in force.
\end{abstract}

It is ironical that the whites also see the apartheid system as a barrier to their freedom also. They don't enjoy the privileges the system is supposed to give them as it alienates them to the blacks. The different races live in suspicion of each other and though some may be working together they still don't have complete trust for each other. In Blood Knot, Zachariah doesn't trust his brother when he tells him that the reason for the rise in the price for the foot salts he uses on his sore feet is because of it having better quality. In Hallo and Good - Bye the two siblings Johnnie and Hester are suspicious of each other. Johnnie suspects that his sister is up to something and that is why she has come back after being away from home for so long. Hester also suspects that her brother Johnnie knows where their father has kept the money she desperately needs. The South African blacks and whites live in suspicion of each other not trusting each other like the two siblings.

Hester does not know that the father has nothing worthy to be inherited. He owns nothing apart from the clutches he uses for walking because he is crippled. Apartheid has nothing to be inherited. The system only cripples the minds of the citizens with fear and intimidation.

As stated in his introduction, Athol Fugard stages Blood Knot a play involving two brothers symbolically. Zachariah is symbolic of the black people and his younger brother Morris is symbolic of the whites. Fugard with his long time black friend Zakes Mokae form the cast. His black friend takes the part of Zachariah as he himself takes the part of Morris. They have diverse ways of doing things to show how the blacks and whites live in South Africa. Morris is the decision maker while his brother is overworked and has no say regarding the management of the money he earns. This shows that the blacks work but have no say over the resources in South Africa. Morris survives on the sweat of his brother. This is exploitation.

Fugard has a unique style of using minimal physical characters alongside others who are physically absent though very important in the story line of the play. In this play he uses only two physically present characters. Others are absent and we know them through flashbacks. The two brothers' parents are supposedly dead but their mention is highly symbolic. Their absence lays ground for the two brothers' mysterious questions about their difference in colour and the effects of the same in their lives. Zachariah wonders who of the two between him and Morris was the real child of their late mother and if they were really brothers why they were so different. Zachariah cannot comprehend why when they were young the mother favoured Morris by buying him toys while he had to do with home-made ones that were not attractive.

Historically South Africa was a colony of the British and the people needed their freedom. In a monologue in Hello and Good - Bye, Johnnie states "Queen Victoria's statue is on the square and during the day pigeons sit on it..." (3) This 
indicates that British rule had been in place for a long time since the queen is a symbol of British power. When independence was granted, the whites hijacked it so that it became theirs leaving the blacks in a worse situation. Before then, it was known in the world that South Africa was a colony and that is why they needed their freedom. After the freedom, the black South Africans are left as internally colonized by their own brothers the white South Africans. Before the arrival of Ethel in the lives of the two brothers, there was no confusion. When she arrives, the two brothers begin to differ. In the same way, Gacheche states in her article 'South African Writing - A Brief Survey' in Gachukia, $(1978$, p.196) that:

The live and let live attitude was all very well in the South Africa of 1910 to 1948 but after the ascension of the Nationalist party, no one could afford to be impartial anymore. The African had seen the vulnerability of the white man in Second World War and as getting organized in trade unions and political parties aimed at getting some of the benefits of South African affluence. In the face of this consciousness and the black menace, the white man was consolidating his position and issuing manifestos.

These manifestos were about separate development which is in reality apartheid as we also experience when Ethel gets into the scene though invisible. The two brothers had lived well although Morris was always a burden to his brother as he had to be fed from Zachariah's hard earned and meagre wages. Historically, the two races had lived without so many differences before the British declared independence for South Africa like it was doing for other states in Africa. This leaves us wondering whether the freedom granted to South Africa by the British was meant for only the white inhabitants or for everybody in South Africa.

Athol Fugard tries to demystify this question by bringing in minimal characters as representatives from both races to express his social vision. Some other characters are however mentioned to enhance the story line but they never appear physically although they are very important in explaining his social vision. There appears an old woman in an illusion who claims to be the two brothers' mother but they soon realize she is not. They try to chase her away but she stubbornly refuses to go. They don't succeed because each one of them tries to chase away the woman separately. However the two brothers work together, they succeed in chasing her away. Fugard's vision is that the whites and blacks work together like the two brothers. The blacks should work alongside the whites in order to succeed in overcoming apartheid.

Fugard's vision is that no race be disadvantaged by the skin colour in terms of power. The characters have been examined with regards to the relationship between power and the people in this society. In the case of South Africa as said earlier it was all about one's colour. Gergen, K. and Mary Gergen, (1981,p.5) assert that the understanding of the world in an orderly way and why things happen as they do, the social psychologist relies on psychological concepts such as thought, affect, attitude, expectancy and rule. In the case of Fugard's characters, the blacks are subjected to a harsh rule by the whites as realised in Fugard's Blood Knot, (1987) where the black character Zachariah is made to work at the gate where he stands the whole day and despite getting his feet sore the white boss does not change his job for another but instead ignores him.

Socially Zachariah is deprived because he is black and so nobody can listen to him despite the fact that he is suffering physically. His boss is a white man who ignores his cry because his colour gives him the power to do so. Even the language used by the boss is abusive and the reader is left to wonder why Zachariah should continue working in such conditions. The reason is that he has no option. It is either the job or he starves because he is disadvantaged by his colour. He is illiterate and has no training to give him skill to enable him to work wherever he wills. From Chris Wanjala in an article 'Fossilized Black Martyrs' edited in Eddah Gachukia and Kichamu Akivaga, (1978) we learn that the blacks were victimised by the law imposing passes to restrict their movement. The blacks had to move with passes to allow them to move from place to place and also give them opportunities to get jobs.

The vision that Fugard is communicating is that there is need for change in all spheres in South Africa. That change can only be realised through the blacks and whites working for it. Morris doesn't see the need for the change in their diet. The white man does not see the reason for change because he is enjoying as we realise that Morris doesn't mind because he is not the one who does the same job at the gate of the factory. Fugard uses Morris to inform his brother that what he earns is so little that he is always struggling. Morris asserts that it is difficult to work on growth needs if one has deficiency needs and that one cannot proceed if one is struggling and spending a lot of time trying to survive. In the case of Zachariah he is trying to survive by working in a factory where no one cares about his physical and financial well-being. Fugard's vision is that the blacks should realise that they are oppressed by the whites economically, socially and politically. Economic oppression is brought about by the poor wages they get from the employer.

Fugard makes use of absent characters to enhance his social vision... It all starts with Zachariah when his eyes 
wander through their window and he sees donkeys mating. His sexual desires are aroused and he remembers that a whole year has elapsed since he had a woman. We encounter the relationship of power and colour when the two brothers have an encounter with a pen pal as Morris again makes a decision that Zachariah should have a pen pal. The two buy a newspaper and look for the pen pals. Morris has the upper hand because he can read names from a newspaper and Zachariah cannot. He chooses the name of the pen pal. The choice name is Ethel. She doesn't at any one time appear but when she comes in the story, the lives of the two brothers change. The dialogue below shows that Zacharia is not comfortable with names he hasn't encountered.

Morris: Well Zach, you ready? There are three women here. The young ladies Ethel Lange, Nellie de wet, and Betty Jones...

Zacharia: There is no Connie is there Morrie..." (22)

\subsection{Athol Fugard's social vision in Hallo and Good - Bye}

In Hallo and Good - Bye, the playwright makes use of two characters Johnnie and his sister Hester together with absent and dead characters as their parents. These two also represent the two races in South Africa. The play begins with Johnnie who is alone in an empty room. This is symbolic in that Johnnie has an only sister who is also lonely but they cannot live together. The empty room is symbolic of the emptiness in the lives of the blacks in South Africa. Hester is only interested in inheritance from her father but Johnnie takes care of his ailing and crippled father. When the father dies he feels so lonely and desperate that he doesn't know what to do. Fugard makes use of flashbacks and monologues to explain why certain circumstances are the way they are. An example is the reason why Johnnie's father is a cripple. It is because of an accident he got and he had one leg amputated. He walks with the help of clutches. When he dies his son can only inherit the clutches. This is symbolic of apartheid in that it is crippling and there is nothing worthy inheriting from the system. If there is anything to be inherited from apartheid it is the crippling effect on the citizens. Johnnie is lonely and alienated to his sister Hester. When she arrives expecting a warm welcome from her brother she is shocked to realize that he is neither exited to see her nor interested in talking with her.

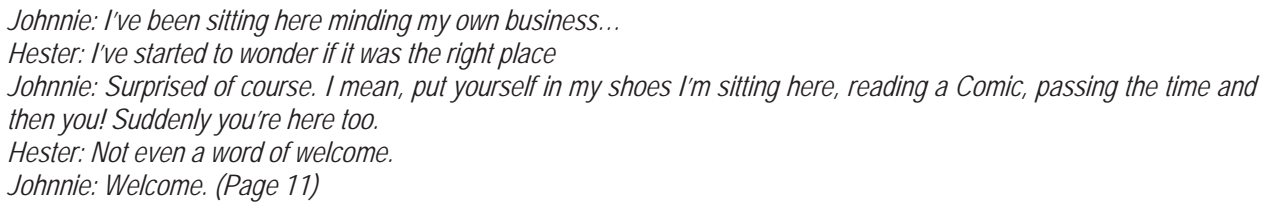

That conversation is in itself cold. "The welcome" statement is only said after Hester demanding it. Hester has been away for twelve years and her brother is not exited at all about her visit lonely as he may be. The exclamation mark in the conversation "... you!" shows unfriendliness. This is abnormal for a brother who is now an orphan and so lonely. He ought to be excited to see his sister. Fugard is showing us that the relationship between the blacks and whites in South Africa is so sore that they don't so much care what happens to the other. The blacks have always been in South Africa and have never left because this is their home. Johnnie has been at home and has never left even when his crippled father becomes so impossibly dependent on him he doesn't desert him. Hester goes away leaving his brother who is actually younger than her with a huge responsibility of taking care of an ailing crippled father. No wonder Johnnie is not interested in her. The whites are interested with the material wealth they get from South Africa like Hester.

When asked how long she would be staying in the house, Hester ignores the question and starts talking about the twelve years she has been away in a flashback. Out there she is not comfortable and she has really suffered. Like Morris in Blood Knot, Hester comes back to her brother. She is back because out there she has no money and she needs to live. She has come to see if her father has anything for her to inherit since she is his child. The whites need South Africa as much as the blacks. The only difference is that they want to take what they have not worked for. Hester has not cared for her ailing father and yet she wants to get inheritance. Johnnie has been looking after the father and is not asking for anything. He has been doing it as a duty to her father as a son. Johnnie insists on asking his sister why she has come back.

Johnnie: Why have you come back?

Hester: It is also my home. I've got a right to come here if I want. I'm still his daughter. How is he?

Johnnie: How long you staying? 
Hester: What you worried about? I will buy my own food.

Johnnie: Is this a holiday? Back home for old times' sake sort of thing. Two weeks annually.

Hester: In here? I got better things to do with my holidays. (11)

This conversation shows mistrust between Johnnie and his sister Hester which is symbolic of the mistrust in the blacks and whites for each other. Johnnie doesn't trust his sister at all and suspects she is up to something. Hester was not at all interested in her father. Her relationship with her father is sore and she doesn't care about it. All she needs from her father is her inheritance. Johnnie also tells Hester that when she left, her father had said that no one was going to speak of her again. He hated her and had said that she was not a real Afrikaner like him by nature as she had the English blood of her mother. When she asks Johnnie whether the old man still hates her and he replies in the affirmative, her response is "So what? Just remember mom didn't hate me and half of this house is hers so I'm entitled to be here."(11)It is ironical that such words can be spoken by a daughter.

Johnnie pesters his sister further by also asking her whether she has actually come back for something to which she does not give a direct reply but goes round and round by replying that she hadn't stated it. She is hypocritical. She doesn't disclose her mission at first but later she makes her advance by telling Johnnie to bring her all the boxes in the house she needed to search for something. She claims that their father was paid hundreds of pounds for compensation after the accident that crippled him and it was hidden somewhere and that is why she needed to ransack all the boxes in the house.

Through Hester the theme of greed is explored and through the father racism is expressed by the fact that he hates his daughter and adores the son who he claims to have inherited his Afrikaner blood.It is then that Johnnie realizes and asks the sister "So that's it? That's why you've come back!"(25) There is racism in South Africa and through Hester, it is evident that one race is only interested in exploiting the other. Hester goes further than that and asks her brother what would have happened to her half share if the father had died in her absence. Johnnie urges her not to mention their father's death but she doesn't care saying that “...I'm still alive, you see. He is passing away but l'm still alive. And l'm his daughter. So half of that compensation is mine."(26) The search for the treasure begins and goes on for a long time but finally there is nothing to be inherited showing the futility of the regime.

\subsection{Athol Fugard's social vision in the Island}

In The Island Fugard makes use of two characters Winston and John who are locked in a cell which is a small clumsy room in Robben Island. The presence of sand in the play maybe mistaken to be an additive to the description of the setting given the title of the play is "The Island". A closer look reveals that the imagery of the sand is fundamental to the understanding of the text. The sane represents various meanings at multiple levels.

Fugard has creatively employed the imagery of the sand to portray the herculean task blacks are up against in their bid to stem out apartheid. This is best illustrated by the following lines:

Each in turn fills a wheelbarrow and with great effort pushes it to where the other man is digging, and empties it. As a result, the piles of sand never diminish. Their labor is interminable. The only sounds are the grunts as they dig, the squeals of the wheel-barrows as they circle the cell, and the hum of Hodoshe, the green carrion fly (page 47).

This repetitive exercise leads the prisoners to a senseless state of hopelessness, despair and exhaustion. By depicting the labour as never ending, Fugard has made an attempt to vivify the tiresome and gruel some nature of apartheid. It is actually impossible for the prisoners to progress in shifting the sand and filling the holes since the task is cyclic. This scene demonstrates what prisoners experienced in apartheid jails.

The struggle to make progress against the unending mounds of sand best illustrates a struggle to overcome the oppressive apartheid policy by blacks in South Africa. The unending labour has been used by the playwright to exemplify the hardships blacks were subjected to and how they endlessly worked to overcome their plight. Besides, the apartheid laws as applied by the authorities deprived blacks of their basic human right; a right to freedom of movement and interaction. Fugard has captured this by taking us to prison where Winston and John have been confined. By making them dig and move the sand, these men have been denied of the luxuries and pleasures other free people enjoy. These sentiments are echoed by Winston who tells John that he is going to enjoy beer and women once he is freed.

And is composed of several grains and it comes along in various colours. Fugard uses the individual grains to illustrate the separateness that defines the apartheid system. At the same time, Fugard uses sand's different colours to represent South Africa's different races. The separateness of the sand is also symbolic of the systematic break of the 
prisoners. The playwright seems to draw a line between the sand on which Winston and John are working on and the rocks that old Harry is working on. Old Harry seems to have reconciled himself with life in prison as his depressed mannerisms point at someone who has been turned into a stone. On the other hand, Winston is disillusioned by the news of John's imminent release. The playwright juxtaposes the impact prison life has had on old Harry and other prisoners. This is captured in the following lines:

When you go to the quarry tomorrow, take a good look at old Harry. Look into his eyes, John. Look at his hands. They've changed him. They've turned him into stone. Watch him work with that chisel and hammer. Twenty perfect blocks of stone every day. Nobody else can do it like him. He loves stone. That is why they're nice to him. He's forgotten himself. He's forgotten everything... why he's here, where he comes from (71).

Old Harry has been made to understand that prison is his second home hence killing any hope in him of ever making it out of prison. The imagery of old Harry being 'a stone' points at extreme level of someone being broken down. The authorities have succeeded in breaking down their prisoners though differently.

The portrayal of the beach may be misleading since at face value it can be thought of as a place to have fun. This could be true when the two prisoners reminiscent the time they spent at the beach. However, the ground on the beach is an unstable one. If one is walking or working on its surface there is the possibility of sinking. This shows the instability that has been brought to South Africa as a result of imposing the apartheid laws. Similarly, it is hard for blacks to make any progress in fighting apartheid as the ground on which they are standing is unstable. The labour situation of Winston and John where they are to move sand on sand exemplifies the lack of stability for blacks.

The apartheid laws have made it possible for whites to lead a stable life while blacks lead an unstable one. Hence, we can say that blacks are living on sand while whites are living on stable stone. Black's instability arises as a result of their confinement, oppression, torture and the repressive regime of apartheid. Fugard wants the reader to see how it is virtually impossible for blacks to make any progress while the stage has been set for white supremacy.

History has it that Nelson Mandela the first black South African president was imprisoned for twenty seven years for leading the ANC (African National Congress) a the South Africa that was demanding for equal rights with the whites. In this play, we encounter misuse of power where two inmates are ill treated. They are overworked and beaten as a mode of punishment. These two characters are also subjected to pain by an unfair guard who treats them inhumanly. The readers or the audiences watching this play are left wondering what reason there is behind the inhuman behaviour of the warden towards the prisoners. The only possible answer is that the white man does not view the blacks as an equal human being who has human rights like his. The two men are imprisoned in a jail in an island. This is symbolic of the jail where Nelson Mandela the historical hero of South Africa spent twenty seven years. The playwright introduces a play within a play making the two inmates to take different parts in Sophocles' Antigone.

In this play, the position of the character is established through what they are made to do and say. There are also absent characters like the inmates' family members, Hodoshe the harsh warden and other inmates in other cells in the same jail who do not appear physically but have a great impact on the characters on stage. Both races live in mistrust and suspicion for each other. The two inmates in a prison cell in a lonely island live in fear of the white guard Hodoshe. They are subjected to physical torture and hard labour.

\subsection{Athol Fugard's social vision In Master Harold and the Boys}

In Master Harold and the Boys, the play opens in a hotel room. The playwright presents three characters that appear physically on stage but there is mention of other absent but core characters. His parents are absent characters. His father who is ailing is said to be hospitalized and his mother has gone to visit him. This father is also a cripple and uses clutches to walk. Two of the characters Sam and Willie are black and they do cleaning jobs in a hotel owned by the parents of the third character Hally. Hally is the short form for Harold. He is young and that is why he is referred to as Master Harold instead of Mister. Master Harold and the Boys is a play about a teenage white boy caught up in the psychological problems brought to him by apartheid laws which he cannot follow as he is supposed to. The other great problem he has is about his alcoholic father whose impact in the home is negative. He is so much involved in drinking that his hands are off as far as the family affairs are concerned. The black servants, Willie and Sam know Hally's mother as their employer at the Jubilee Residential House and later at the Tearoom because most of the times Hally's father is too drunk to even know what goes on in the place of work. The two black servants are an integral part of Hally's childhood and they are his close friends. Hally shares the education he gets from school and also from text books. Sam embraces the knowledge as he also gives Hally important knowledge about a healthy relationship with other despite the 
obstacles of the apartheid regime. Sam replaces Hally' father in the issues of the lessons a child should receive from a father as he grows up. He therefore emerges as a good surrogate father to Hally despite the racial segregated environment and the distraction from an alcoholic father.

As Fugard writes, Apartheid policy is in place in South African and so the play addresses the issues in the context of that regime. The playwright presents us with his social vision. The title of the play shows the racial hierarchy as a characteristic of South Africa during the apartheid.From the title, we realise that 'Master' is used to refer to whites and 'boys' is meant to refers to blacks. Through the characters in the play, Fugard presents his social vision as one of racial reconciliation, and harmonious co-existence. This has been missing due to the dehumanising nature of the apartheid policy. Sam and Willie are adults but they are referred to as boys because they are black and servants. That shows that the position of the blacks in South Africa is inferior to that of the whites who are superior because of their skin colour.

The three characters are friendly but at some point Hally realizes that his position is different from the other two because he is white. He tells Sam that his father has always told him to keep his distance with the black workers who are referred to as boys. He then says that he is now aware that he ought to have done it earlier and that it is overdue. There is a dancing competition and cripples are said to spoil the dance floor with their clutches. This is also symbolic. The cripples symbolize the whites. They are the masters but they are cripples. They depend on the blacks to do difficult tasks. Hally's father gets himself drunk and he can't walk. Sam has to carry him on his back and then clean him up because he has messed in his trousers. Hally himself couldn't fly a kite on his own. He always depended on Sam.

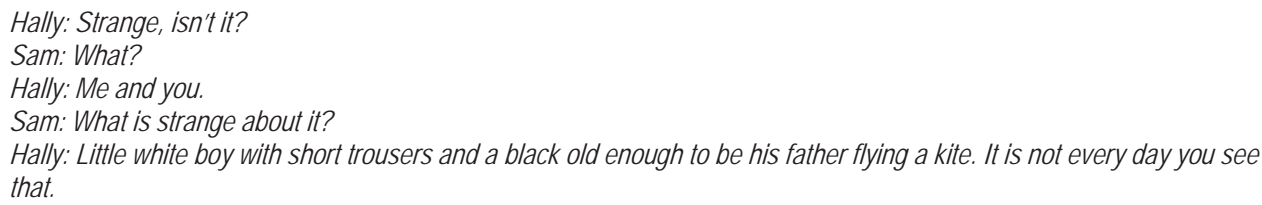

Hally admits that he can never fly a kite alone and that there is no chance of his succeeding without it being strange. This statement is loaded with information that on one hand it is strange that if there is going to be any success in flying a kite Sam must be there and he is a black. On the other hand it is true that Hally needs a grown up to help him fly a kite and it can never be his father because although he is a grown up, he is a cripple. A cripple can only distract the kite from flying. The playwright is suggesting here that though Sam is black and therefore supposedly inferior due his skin colour, there are things the white youth cannot do on his own despite the assumed superiority of his skin colour.

Despite having the ability to make Hally's kite fly, Sam's position is still below that one of Hally who is a child and cannot fly a kite himself. All this is because of the skin colour. With regards to this inferiority of the blacks, Marger, (1999) in discussing systems of stratification states that in closed societies, mobility is uncommon as political and cultural norms and values dictate against it. He continues to state that people are assigned a status at birth as in the state of caste systems. He asserts that in the case of slavery in America, there was a system that operated as a paternalistic domination resembling a parent - child relationship between master and slave. In the case of Fugard's characters Sam's lower position is due to his colour.

The play is heavily influenced by Fugard's childhood. In a way, the play allows him to reconcile with his past, especially family ties. The relationship between Fugard and his father is central to the play as it shapes and moulds the character 'Hally'. By extension, this is what we experience in this play and in Fugard's other dramas. The relationship of Hally towards his father can be described as one riddled with emotions, love hate and resentment.

Through the free indirect style of narrating, the playwright allows us to enter into the mind of his characters. AS a result we get to know a character's thoughts at the same time we get a glimpse of what is taking place in their external world. The following line exemplifies this. Hally confesses. "I love him..." (58). This admittance comes in the wake of Hally expressing his desire not to see his father. Through this, fugard demonstrates that there is still a bond between father and son despite the absenteeism. Fugard's Master Harold ....and the boys is a play with a simple setting which allows for shift of attention to the characters. The playwright from the onset projects one of his major concerns through his two main characters Sam and Hally. Their relationship between the two can be described as that of employer and employee; companion and companion; and father and son.

From the telephone conversations between Hally and his mother, it emerges that Hally's father is in the hospital. Hence, Hally's father becomes an absentee father. This scenario creates a gap in a nuclear family setting. It is this gap that Sam fills. Hally as a child needs a man, a model to look up to; one who can take care of his psychological and 
material needs. That is why Hally and Sam's relationship assume the path of father-son. From the play Sam is seen encouraging Hally to excel in his studies a role that should be played by his biological father. Sam also plays a crucial role in soothing Hally after the telephone conversation with his mother.

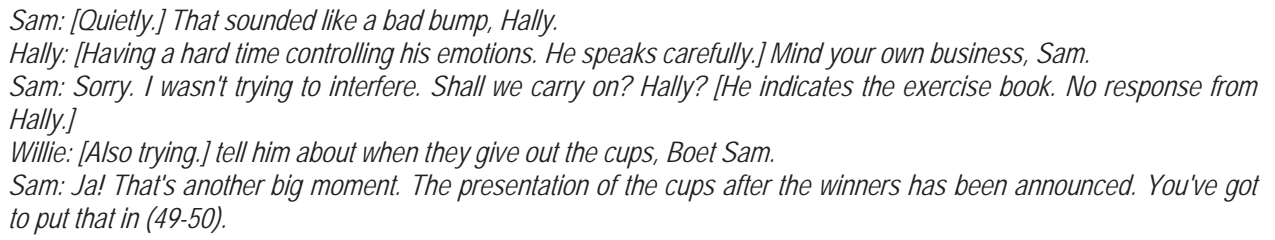

From the above excerpt, it is clear that the subject of Hally's father is a sensitive one. Hally's reaction to the news of his father's return home points at some form of conflict between the two. Since Hally's father is absent from home, he finds one in Sam. Fugard presents us with a character that has to deal with the 'loss' of his father at a tender age. This loss creates a sense of desperation in Hally who in his quest to fill the gap left by his father finds solace in one of his mother's employee.

Hally's relationship with his father can be said to be a distant one or superficial. This can be partly explained by the burden left to Hally, that of tending his father's gammy leg and two due to his father's physical condition. As a young boy Hally needs to be emotionally connected with his father. Contrary to this, his father is physically and psychologically absent from Hally's life. Hence, Hally comes to resent his father's physical weakness, absentness and negative political views. His father's absentness can be seen in terms of political views. Besides, as a man, Hally's father has failed to portray himself as a perfect head of the family. Sam also empahtically says that he does not recognize Hally's father as his boss because he does not pay him. The title goes to Hally's mother. Fugard's parentage has played a big role on how he dramatizes the tensions he is writing about. Fugard is born to an Afrikaner mother and a father who is of English decent. These differences of origin to his parents have compelled Fugard to express the religious, political and racial conflicts that accompany them.

For instance, the discussion between his main characters, Sam and Hally, on who should be regarded as 'a man of magnitude' demonstrate religious differences of his time. There is an evident gap between two beliefs, one, a belief of the evolution and the biblical teaching of creation. Hally cites Charles Darwin as his 'man of magnitude' since he is someone "...who benefitted all mankind" (19-20). Hally's admiration of Charles Darwin's Theory of Evolution is in stark contrast with Sam's views. Hally argues that the theory answers the question of the origin of the human race. According to Hally, the theory proves "where we come from and what it all means" (19). Sam on the other hand totally refutes Hallys claim by stating that Jesus Christ is his 'man of magnitude'. Sam postulates that the theory of Evolution contradicts the Bible's founded belief that humankind are a creation of God. Sam disqualifies Hally by saying that Hally does not have "...to believe it" (20) just it is written in a book.

The different religious opinions emerge as Sam strongly believes that Jesus Christ is 'a man of magnitude'. It is not expected of Hally to share the same views as Sam since he blankly declares that he is "an atheist" (22). This difference in opinion between Hally and Sam captures the religious tensions in the society the playwright is writing about where there was a general acceptance of the Theory of Evolution and the preference for the teachings of Jesus Christ.

\section{How Apartheid Influences Athol Fugard's Social Vision as Presented in the Four Plays}

Fugard has tried to bring to the fore the impact of Apartheid in South Africa through various ways. One is though the use of the slang 'boys'. The term has been used to refer to the black servants. The other way is through the use of the kite. It is strange that a small white boy can be seen in company of an old black man old enough to be his father flying a kite. However, this does not strike Hally who through his childhood innocence does not realize that Sam cannot sit with him and watch the kite fly since it is a "whites only bench" ( 58).

Fugard establishes s sense of guilt and hierarchy in his play. He does this successfully by making his characters look up and down. For instance, at the opening of the text, Willie is on his knees scrubbing the floor, an act which illuminates on the oppression blacks go through. In another incident, Sam instructs Willie not to "...look down..." (4) as he rehearses the quick dance. The same idea of looking up and down is also seen in the case of Hally, Sam and the kite. Sam informs Hally that he only made him the kite because he wanted him (Hally) "...to look up..." (58).

In playing his role as a father, Sam offers Hally choices on how he should lead his life in the Apartheid South 
Africa. He faces Hally and says to him, "that's not the way a boy grows up to be a man... but the one person who should have been teaching you what that means was the cause of your shame" (58). Sam warns Hally of the repercussions that can befall him if he continues to support Apartheid. He emphasises his point by saying, "you're going to be sitting up there by yourself for a long time to come and there won't be a kite in the sky" ( 58-59). Sam demonstrates to Hally of the Ioneliness, and isolation that he risks if he chooses to support Apartheid. Hally in this case risks losing the friendship and companionship of Sam and Willie and by extension the entire black population. Fugard has applied the case of the weather to his play to demonstrate that even though the act of flying a kite is a symbol of racial unity, it can only be meaningful in certain situations. That is, the kite can only fly in a good weather.

Another demonstration of the racial tension in South Africa is Sam's discussion with Hally after Hally learns that his father has returned home. Sam rebukes Hally's treatment of his father and his attitude towards him. Hally is angered when Sam lets him know that he is "treading on dangerous ground" (54). Hally in retaliation tells Sam that his "mother is right" ( 55) when she warns him against "allowing you to get too familiar" ( 55). The argument climaxes as: "You must teach the boys to show you more respect, my son" (55).

Hally takes to racism as he vents his anger out on Sam and Willie. He assumes a boss like role and does away with their friendship. He astonishingly orders Sam to address him as "Master Harold" (54). Sam responds by saying that if Hally forces him to call him Master Harold then it will be the end of their friendship. Hally exhibits a character similar to that of his father and other whites in general. This is especially so when he spits on Sam's face thereby earning his title 'Master Harold'. It this act, apartheid triumphs as Hally assumes his place at the of racial prejudice. The playwright sums it up as, "If you're not careful . . . Master Harold . . . you're going to be sitting up there by yourself for a long time to come, and there won't be a kite in the sky"(58).

The playwright projects the theme of education through Sam and Hally. Fugard uses a young white boy Hally and a black old man Sam to bring out the inherent differences. One of the themes that prominently feature in Fugard's text is education. The subject of education is an important to the playwright's quest of illuminating on apartheid as it offers him one of the avenues to show the policy's inequalities. There are different reactions to the issues of education from Fugard's character. And there are also different levels of learning. Hally indicates his resentment to the kind of education he is receiving but on the other hand he prides in instructing Sam with the same content. Hally also learns from Willie on the fundamentals of ballroom dancing like purgatory/cathartic effect and its inherent beauty. Willie's words offer Hally the much needed inspiration to attempt his homework. This is especially so when Willie's mentorship acts as an eye opener to Hally to an otherwise ignored aspect of the dancing.

Hally's boredom with education is captured when Willie inquires about school: "Yes, Master Hally! Schooling okay today?" (12). His response to Willie's enquiry is an astonishing one. He replies after some moments of contemplation, "No, not really. Ag, what's the difference? I don't care..." (12). His dislike of the education system is further captured by Fugard when hally says: "Write five hundred words describing an annual event of cultural or historical significance" (35). Hally trivialises the essay topic by contemplating on basing his essay on Sam and Willie's ballroom championship, a competition that he disregards. He opts for the ballroom dance since he hopes to "...teach the old bugger a lesson" (43). It is clear that Hally is not dwelling on the championship because it merits its place as a serious subject of study rather he is using it to hit back at his English teacher.

Hally's negative attitude towards school is contrasted with the enthusiasm he displays when he is teaching Sam. It is evident that Sam has been a good student since Hally was in fourth grade. As Sam goes through Hally's notes he encounters words he cannot comprehend and Hally supplies Sam with simpler synonyms. Sam's limited grasp of the English vocabulary and on the other hand Hally's masterly of the same has been used by the playwright to illustrate the hierarchy in education where whites are learned while blacks are not. It is ironical that Sam who is old enough to be Hally's father is receiving education from a teen. This reversal of roles demonstrates the inverted lives of blacks.

There is an evident gap between blacks and whites. This is what Fugard has attempted to capture through the kite. The racial gap emerges prominently when Sam gives his reason for not staying with Hally as the kite flew because it was a "Whites only bench" ( 58). To a large extent, this barring notice illustrates the mechanisms put in place by white to control and confine blacks. However, by the mere incident that Hally could fly a kite with Sam is telling of the playwright's hope of a South African society devoid of racial barriers. This hope is expressed when Hally and Sam once the kite is in the sky they raised their heads to look at the flying kite. The act of Sam and Hally jointly looking at the kite symbolises blacks and whites coming together for their common good. The kite serves to give hope to an otherwise depressed and dejected South African society that a day is coming when whites and blacks are going to stand together with their heads held high with pride and in dignity.

Through the kite, Fugard has been able to project his social vision of racial unity as Hally and Sam acknowledge 
that it is only possible to fly a kite in "...better weather..." ( 59). 'Better weather' in this case can only refer to peace and harmony, when blacks and whites speak with one voice and consider each other as equal members of the society. The playwright has thus used the kite to underscore the need for peaceful co-existence and an end to Apartheid.

We can therefore conclude that there are two ways of narrating the story: Sam's version and Hally's version. From Hally's point of view we get to know the naivety that is involved in dealing with Apartheids in South Africa. This is exemplified by Hally's feelings that the kite may not fly. Hally shows a lack of faith in Sam in doing an act that he has not learnt from his father.

The kite presents Hally with a moment of marvel. However, in as far as the kite denotes freedom, it also alludes to restriction. We are told that the kite can only fly as far as the string can allow. In a similar manner can Hally and Sam's relationship blossom up to the end of Hally's youth or ignorance. Fugard has employed the mode of the kite to point at the limitations existing in the South African Society; the racial boundaries. This limitation can only be overcome through acceptance which is lacking on the side of Hally and whites at large. This is further illustrated by Sam who deserts hally once the kite soars to the end os the string since he could not sit on a 'white only' bench.

Hally's relationship with their waiter Sam is also central to the play Master Harold and the boys and to Hally's life as a boy. Sam Semela is a waiter at The Jubilee Residential Hotel. This contact brings about an absurdity characteristic of Apartheid South Africa. Young Hally is barely a teen but in charge of men old enough to be his father. This strangeness accords Hally the ability to recognize manly qualities within Sam that makes Hally adapt him as his surrogate father. Hally is seen desiring to model himself after Sam.Hally is fond of Sam who is working for them. This is because of their shared interests and activities. Both can be seen reading together and entertain each other at the servants' room.

The kite also represents hope and the undying spirit of black South Africans. One sees the kite flying: "The part that scared me, though, was when you showed me how to make it dive down to the ground and then just when it was on the point of crashing, swoop up again!" (30). At times it comes down to the ground only for it to rise up again. It signifies that blacks can attain unexpected heights by just believing.

The bench is another symbol employed by Fugard in his attempt to illuminate the oppressive nature of Apartheid. Sam and Hally take the kite to the park to fly it. A young Hally is taken aback by Sam's absence soon after the kite soars. Through this, Fugard is bringing to the fore that even at a tender age, young whites in South Africa were subjected to certain social injustices that they were unaware of however much they may not agree with them. That is why later in the text, Sam tells Hally that, "All you have to do is stand up and walk away from it (60) Sam's statements indicates that Hally is now knowledgeable and it is within his resolve to choose right from wrong. After his dispute with Sam, Hally chooses to leave them. This act portrays South African whites' character's inability to confront the vices of their society.

\section{Polyphonic Depiction of Characters Who Carry Fugard's Voice and His Relevance}

Polyphony in this study is all about the different voices in the four selected plays that carry the playwright's social vision. Some characters are used by the playwright to communicate his social vision. These characters are naïve at first in that they either don't know their position in the racist society or if they know they have resigned to fate. Relevance is all about the significance of the characters and their roles to the playwright's social vision.

Athol Fugard begins by giving them a burden of seeking for their identity. Identity quest is all about hunger for selffulfillment or assertion of self; it is also a pursuit for freedom and a discovery for meaning in one's life. In the four plays of this research The Island, Hello and Goodbye, Blood Knot and Master Harold and the Boys, the playwright shows that the characters are looking for their identity through their roles. They struggle until they find themselves in the end. It is through the struggle that we realize Fugard's social vision.

\section{Polyphonic Depiction of Characters}

In the play The Island it is through the heroine of the play 'Antigone' that the author opens the eyes of his audience to see the reality of the misuse of power as a theme in this play. 'Antigone' the character is a sister of two brothers who die in battle though on different sides and she buries the body of one because it has been left unburied. This concurs with Weirtheim , (2000) who states: "the audience however begins to realize that Fugard has chosen the Antigone story because it is a legend that embodies the history of protest and Winston's life is thus a history and legend in one."(93)The character Winston therefore stands for those who represent historical legends in South Africa. A good example is Nelson Mandela who in 1990 was released from a jail term he had served for twenty seven years comparable to Winston's cell. 
It is only after the two inmates get a surprise call from outside their cell and then the news that John would be released in three months to come, that Winston sees his own image in old Harry another old prisoner who is jailed for life. Old Harry is a seventy year-old prisoner serving a life sentence like Winston and he worked at the quarry with such perfection that it was like he had forgotten himself. Winston then says:

They have turned him into stone. Watch him work with that chisel and hammer twenty perfect blocks of stone every day. Nobody else can do it like him. He loves everything... why he is here, where he comes from. That's happening to me John. I've forgotten who I'm. (71)

Winston realizes that he doesn't know himself and hence the quest for identity. 'Antigone' the character in the play Antigone is used to open the eyes not only of the character Winston but the audience too. This is the height of Fugard's vision for the people of South Africa. Winston sinks to the floor, helpless and tormented about the stretch life in the island and sees the reality of it. Fugard juxtaposes the life of Winston and the hopelessness with that of John who is about to be released to show the reality of the blacks in South Africa. Through Winston Fugard is showing that the blacks ought to see the reality about their position and fight for their rights. At last Winston who has been reluctant is now more than willing to stage the play Antigone and to take the part of 'Antigone'. He tells John: "Yes come, we'll be late for the concert to show that he is eager to act as he has now realized that the play is realistic and it carries some sentiments about his suffering. (73) Winston's voice is heard for the first time since they begun arguing about the cast in Antigone as carrying Fugard's social vision.

Fugard's hope is that as Winston has at least found himself in acting the part of Antigone, the blacks will find themselves in the character of Winston and get provoked to fight for their rights. John takes the part of Creon the King while Winston takes the part of 'Antigone' the sister of the two men who had both died in the same battle field though fighting on different sides. Antigone pleads guilty of burying her brother Polynices. When her charges were read as: "You are accused that, in defiance of the law, you buried the body of the traitor Polynices."(75) Her response was: "I buried the body of my brother Polynices here."(71) The author is showing us the strength of 'Antigone' in that she is impartial. She states categorically that when Polynices died in battle regardless of what side he was in, all that remained was a dead body which could neither harm nor help anybody. She says that what lay in the field belonged to God and tells Creon that though he is a king he is only a man. She goes on to state that as there are laws from man there are also laws from God and that is what she fulfilled. Antigone is brave. She doesn't fear even death and tells the king "Your threat is nothing to me, Creon. But if I had let my mother's son, a son of the land, lie there as food for the Carrion fly, Hodoshe, my soul would never have known peace."(76) She says the words with such finality that it is hard to believe that she is talking to a person who holds her life like King Creon. She has no fear because she stands for truth and says she feels no shame that she is sentenced for life imprisonment in the island. She is brave as she states that she goes to imprisonment without resentment because she is not guilty.

In bringing in Antigone as a play within the main play The Island, Athol Fugard's vision is that the blacks should realize their position and they should like Antigone be brave enough to take their position. Antigone's voice is Fugard's vision in that a person who is sentenced unfairly by unfair laws remains innocent although he may suffer. Like Polynices, they are viewed as traitors and they deserve no honour. Brave people like Antigone should arise and stand for the truth even though it means going to prison.

The fate of the black man is already decided by the white man in that he is inferior and therefore he has no say over anything including his own life. In the play Blood Knot, Fugard uses two characters to illustrate the quest for identity. Zachariah who represents the black is presented by as one who is deprived of his rightsbas a result of his black skin. At one time when he tells his brother Morris that he needs a woman, he is told to get himself a pen pal. This issue comes about when Zachariah looking through the window sees two donkeys mating and it dawns to him that it was a whole year since he had a woman. He remembers the good times he had with an old girlfriend known as Minnie. In the company of his friends they would go out at night and have women. "Hey! I remember now! By hell! About Minnie. How did I forget... it was a woman! That is what we had when we went out at night woman!"(11) Furgard's social vision here is that the African should one day be able to enjoy human rights like the whites.

The problem of the South African blacks needs attention now and not tomorrow. Fugard's vision is that the issues affecting the blacks are not unimportant as the whites think. He makes Zachariah stubborn on the issue of the immediate need for a woman. "What do you think I am? Guess! Two legs and trousers. I am a man. And in this world there is also woman, and one has to get the other. Even donkeys know that."(12) The black man in South Africa is a man who has human rights equal to the white man. The South African whites may not also be very sure of themselves like Hester. When she asks whether her father ever asks about her Johnnie tells her the following: 
When you left, he said, we wouldn't speak about her... You weren't a real Afrikaner by nature, he said. Must be some English blood somewhere on Mommy's side. He hates you. (20)

\section{The Relevance of Fugard's Vision}

This section has attempted to show the relevance of the playwright's social vision. It highlights the hopes Fugard has with regards to the social life of his characters that represents the people of South Africa. The relevance is expressed through the characters that have some a Messianic kind of hope and how they fight through the tough times until it becomes possible for them to come out of the chains of racial inferiority. A messiah saves people in predicaments.

Fugard's social vision is that the people of South Africa will arrive at a decision to defend each other's right like the way Antigone does without fear. The blacks are humans and they need social protection like Polynices needed a decent burial. The whites should realize that the blacks are human beings. Those few whites like the writer who associate with blacks and work with them should be supported. This social vision is not only for South Africa. It is a vision for the whole world as Fugard sees it. It is a vision for all the races and classes in this world. Some nations may not be affected by racial discrimination but there is still the problem of ethnicity as evidenced by tribal wars and class stratification brought about by economic disparities. In an article by John Kenneth Galbraith in Martin Merger's Social Inequality,(1999) Galbraith argues that the social class is the most consequential form of stratification, exceeding ethnicity, gender and all others.(23) Social Class can be classified into economic class and 'lifestyle' Galbraith explains:

Social Class can be understood as groupings of people who share roughly similar incomes and wealth, similar levels of education... income and wealth, occupational prestige and educational level are closely intertwined and together create economic community... classes may be thought of as groupings in which people share not only similar occupations, incomes and levels of education but also similar lifestyles... for example the upper class people generally use different patterns of speech, maintain different tastes of music, fashion and cuisine, decorate their houses differently and prefer different forms of leisure than do either middle class or lower class people.(24)

All these goes to show that Fugard in using Willie Sam and Hally as characters, is showing that in South Africa there is not only racial stratification but also class stratification.

The Class disparity is however brought by the racial discrimination. This is due to the inequality as regards to opportunities in education and economy. Sam and Willie are not educated and therefore they can only work for Hally's parents as hands because they have no skills. Hally is going to school and that will only translate to him being skilled and therefore continue his father's trend. He will also employ Sam and Willies children because they will also be uneducated and hence unskilled. This trend leads to class stratification continuing to generations.

Social classes breed real divisions of society that are also manifested in people's behavior.According to the psychoanalysts ideas in Roberts (1999), behavior is caused by hidden and unconscious motives including the experiences of childhood and adolescence. In assessing fugard characters it is realized that Sam and Willie being black have always felt inferior under the white man and that is why they are referred to as 'boy' though they are in their mid forties. Hally is referred to as 'master' though he is the one who is actually a boy compared to the other two. Hally is a white and given the situation of whiteness and class he feels superior. He replaces his parents and gives orders to Willie and Sam in their absence. This power is accorded to him as a result of his class which goes with colour in South Africa. Fugard establishes his social vision through his characters. He begins by showing the social disparity and the cause for it. He makes sure that the evils of racism are displayed and then brings out his social vision by using the same characters to establish what is socially right for people living as a nation as in the case of South Africa. Fugard's plays are relevant to contemporary life in that the issues he deals with are issues that are found in ordinary life. He brings out the problems and gives solutions using his characters. The solutions are what the study has established as his vision.

In Blood knot, Fugard uses Morris to create a big problem to his brother Zachariah. The arrival of Morris in Zachariah's life brings no good. He spends the whole day at home as Zachariah goes to work. He waits for his brother to provide for his food and shelter. He is a burden. Zachariah complains to his mother in a dream and says. "There is something I need to know. Whose mother were you really?.. No evil feelings, Ma, but I mean, a man's got to know. You see he has been such a burden to me." At the end of the play, there is a solution. Morris says he can't carry on and he has to leave Zachariah. Zachariah tells him as a way of encouragement not to give up." A man can't just stop like that.... a man must carry on." (84) Morris is determined to leave his brother and follow a road wherever it takes him. He wraps his belongings which include his clothes, a Bible and a wall clock. He had written a letter but then realized that his brother Zachariah cannot read. It is then that he realizes that he can't leave his brother. Fugard's vision is here explained. The 
two brothers must live together.

Two races must co-exist in South Africa. They must be there for each other. Then the case about Ethel is revived. The two brothers decide to do away with he pen pal and start their lives as brothers. Fugard hopesthat the people of South Africa can forget the past and start all over.

The black man can also take the lead. No one would imagine that he can. Zachariah has won the suit but it is like he is not sure his mother recognizes him in the white man's attire. The black man will ascend to power and to the amazement of everyone he will make it like Zachariah wearing a suit that he has never won. The white man is lonely without the black man. The black man as represented by Zachariah is realistic and is ready to live the black but the he should also stop tiring him.

\section{Conclusion}

Athol Fugard's plays cannot be read and understood outside the ideals, values and practices of the apartheid regime in South Africa before the black majority were allowed to vote in 1994. Indeed this confirms that literature is given direction and impetus by society. Fugrd's concerns and social vision have therefore greatly been influenced by this racist system that had both psychological and physical effects in different races in South Africa. To Fugard, there is no difference whether one has a black or a white skin. A biblical allusion is used by Sophocles in Antigone in saying that the body that lay in the field belonged to God. God is the creator of all human beings whether good or bad. It is the human law that Creon stands for that judges whether one human being is good or bad but not the law of God .God equates all human beings to his own creation as Antigone alludes when she stated that she will not be guilty before God or any man in this earth. She concludes that she won't mind going to her living death in a long cell because of honouring those things to which honour belongs. These words are said at the very end and the two men John and Winston remove their costumes and go back to their cell in handcuffs as before. These literary and biblical allusions are significant in communicating Fugard's social vision.

\section{Reference}

Fugard, A. (1974). Hello and Goodbye. New York: Oxford University Press.

Fugard, A. (1976). The Island. New York: Vikings Press.

Fugard, A. (1984). Master Harold and the Boys. New York: Penguins.

Fugard, A. (1987). Blood Knot. New York: Oxford University Press.

Adedoja, E.(2010). Social relevance of African literature to the promotion of social values. Kwara State Polytechnic llorin October 2010, Volume 7, No.10 Serial No.82), 2010.

Alan, F.(1970). The Turn of the Novel: The Transition to Modern Fiction. London: O.U.P.

Alan, P.(1948). Cry the Beloved Country. New York: Scribner.

Albert B. L.(1975). The Singer of Tales. N.Y.: Atheneum.

Albert, W.(2000) . The Dramatic Art of Athol Fugard. UK: Indiana University Press.

Alex, I. (1964). What Is Sociology? London: Prentice Hall.

Best, S. (2003). A Beginner's Guide to Social Theory. London: Sage Publications.

Blessler,C. (2007). Literary Criticism: An introduction to Theory Practice. $4^{\text {th }}$ Ed.Upper Saddle River: Pearson Education, Inc.

Bolagun, P. O. (2003). Archetypes in African Literary Oral Literary Traditions: an Exampl J. P. Clark's

Brinkerhoff, D., Lynn, K. and Suzanne T. Ortega. (2005) Essentials of Sociology. USA. Wadsworth Publishing Company.

Brutus,S. (1969). The Writers in Modern Africa. $3^{\text {rd }}$ Ed. New York:Africana Publishing Corp.

Caesar, J. (1973). Drama. U.S.A: Scholastic Magazines Inc.

Carrigan, R. (1970). Theatre in the $20^{\text {th }}$ Century. New York: Tulane.

Cassady, and Pat.(1975). Theater and Drama. USA: NTC Publishing Group.

Cass, J. (1967). Literature and Young Children. London: Oxford University Press.

Chatman, S. (1981). Literary Style. London: Oxford University Press.

Dennis, D. and Cosmos Pieterse (1972). African WritersTalking. London:Heineman Educational Books Ltd.

Dennis, W. (2003). Athol Fugard: Writers and Their Work. Britain:North Cote.

Dennis, E. and Cosmos Pieterse.(1972). African Writers Talking. London: Heinneman Educational Books Ltd.

Durosimi, E. and Marjorie Jones. (1996). New Trends and Generations in African Literature. North Cote. London: James Currey.

Edgar, R. (1999). Writing about Literature: Brief $9^{\text {th }}$ Ed. New Jersey: Prentice Hall.

Elegba, A.(2010). Social Relevance of African Literature to the Promotion of Social Values. Ilorin;Kwara State Polytechnic.

Erapu, L. (1977). John Ruganda's The Burdens. Nairobi: Heinemann Educational Books.

February, V. (1981). Mind Your Colour. London: Kegan Paul InternationalLtd.

Fonagy,P. and Target.(2003). Psychoanalytic Theories. New York: Whurr Publications 
Fonagy P and Bateman.(2004).Psychotherapy for Borderline Personality. New York: Oxford University Press.

Fonagy,P. and Bateman. (2006). Mechanism of Change in Mentalization based Treatment. United Kingdom: JohnWiley.

Fonagy, P.and Bateman. (2008). Psychoanalytic Constructs. New York: Guilford Press.

Friedman,A.(1970). The Transition of Modern Fiction. London: Oxford University Press.

Gachukia E. (1978). Teaching of African Literature in Schools. Nairobi East African Educational Publishers.

Gergen,K and Mary Gergen. Social Psychology. New York: Hacourt Brace Jovanovich.

Gikandi, S. (1987). Reading the African Novel. London: James Currey.

Goldthorpe, J. (). An I ntroduction to Sociology. London: Cambridge University Press

Gray, S. (1982). Athol Fugard. Johannesburg: Mc Graw-Hill.

Griffith, K. (2006). Writing Essays About Literature: A guide and Style Sheet $7^{\text {th }}$ Ed.USA: Michael Rosenberg.

Guerin, W. etal. (1999). A Handbook of Critical Approaches to Literature. New York: Oxford University Press.

Hacker, D. (1969). Rules for Writers $3^{\text {rd }}$ Ed. NewYork: Bedford Books of St. Martins Press.

Hatch, J. and Ted Shine. (1996). Black Theatre. U.SA: Macmillan Publishers.

Head, D. (1994). Nadine Gordimer. Great Britain: CambridgeUniversity Press.

Hill, E. (1981). The Theatre of Black Americans. Vol. 11. Jersey: Prentice Hall.

Hofer, M.(1981). The Roots Of Human Behaviour. USA:W.H.Freeman\&Company.

Inkels, A. (1964). What is Sociology? London: Prentice Hall Inc.

Kabiru, M. and Anne Njenga.(2009). General Psychology and Personality Development. Nairobi:Acme Press.

Leech, G. and Mick Short. (1981). Style and Fiction. London: Longman.

Lord, A.B.(1975). The Singer of Tales.New York:Atheneum.

Lucas, F. (1955). Style. Great Britain: Cassel and Co. Ltd.

Lyons, J. (1981). Language and Linguistics. Great Britain: Cambridge University Press.

Mahoni ,J. Frank ,B. and Tony Romano. Psychology and You. USA: West Publishing Co.

Maag, J. (2004). Behavioral Management. Canada: WadsworthMcgowan.

Mphalele, E. (1972). Voices in The Whirlwind and Other Essays. New York: Hill and Young.

Mott ,E. P. (1965). The Organisation of Society. USA: Prentice Hall Inc.

Ngara, E. (1982). Art and Ideology in the African Novel. Nairobi: Heinemann.

Nuebeck,K.,Mary Nuebeck and Davita Glasberg.(1979) Social Problem New York: Mc Graw Hill Co.

Norton,P.andJosephEsposito.(1994). TheNewEncyclopediaBritannica.vol28.Chicago :Encyclopedia, Britannica Inc.

Parker, K. (1978). The South African Novel in English. New York: Macmillan.

Paton, A. (1948). Cry the Beloved Country. New York: Scribner.

Peck, J. and Martin Coyle. (1993). Literary terms and Criticism New Ed. London: Macmillan.

Ramage, J., John Ben and June Johnson. (1996). The Allyn and Bacon Guide to Writing. New York: Bedford books of St. Martin's Press.

Rose ,I.. P., Peninah M. Glazer and Myron Peretz Grazer. (1990). Sociology. USA. Prentice Hall. Inc.

Robert, C. (1970). Theatre in the Twentieth Century. New York. Tulane Drama Review.

Robert, H. Lauler.(2005). Social Problems and the Quality of Life. USA: Mc Graw Hill Co.

Robert, R.K. (2005). Psychology. USA: John Willey \& Son Inc.

Ruby, C. (1969). Currents in Contemporary Drama. London: Indiana University Press.

Ruganda, J. (1992). Telling the Truth Laughingly. Nairobi. East African Educational Publishers.

Scarlyn, N. (1937). European Drama. Great Britain: C. Tringlin \& Co.

Short, M. (1989). A dictionary of Stylistics. London: Longman.

Styan, J. (1993). Modern Drama in Theory and Practice 3. New York: Britain: Jonathan Cape.

Styan, J. (1993). The Elements of Drama. New York: Cambridge University Press.

Thompson, J. (1982). Sociology. England: Clay Ltd.

Tyson L. (2005). Critical Theory Today. New York: Rout ledge.

Wa Thiong'o, N. (1991). Moving the Centre. Nairobi: Heinemann Educational Books.

Wanjala, C. (1973). Standpoint on African Literature. Nairobi East African Literature Bureau.

Wellek,R.andAustinWarren.(2000). TheoryofLiteratureBritain:JonathanCape. Wertheim, A. (2000). The Dramatic Artof Athol Fugard. UK: Indiana University Press.

William, R. (1968). Drama in Performance. Great Britain: Alden and Mow.

Wilson, N.S. (1937). European Drama. Great Britain: C. Trinling\&Co. 